К. М. Божко

Академія митної служби Украӥни

\title{
ЕКОЛОГО-БІОЛОГІЧНА ХАРАКТЕРИСТИКА ПІВНІЧНОГО ВАРІАНТА БАЙРАЧНИХ ЛІСІВ ПІВДЕННО-СХІДНОЇ УКРАЇНИ
}

\begin{abstract}
Наведено матеріали біогеоценотичних досліджень байрачних лісів північного варіанта. Подано детальний геоботанічний опис і біоекологічну паспортизацію травостою пробних площ. Встановлено залежність видового складу травостою пробних ділянок північного варіанта байрачних лісів від світової структури.

Data on holocoenotic research of the ravine forests are presented in the paper. The research was realized in the spring, summer and autumn of 2004. Detailed geobotanical description and bioecological certification of the herbage plots are given. It was proved that grasses' species composition of the ravine forests depends on light structure directly.
\end{abstract}

\section{Вступ}

Протягом багатьох десятиліть вчені вивчають проблему безлісся наших степів. Виникали різні гіпотези щодо впливу лісової рослинності на грунти у степовій зоні. Як відомо, ще наприкінці XVIII століття виникла ідея підвищення лісистості степової зони, а з 1843 року розпочато степове лісорозведення. Захисне лісорозведення посідає одне з найважливіших місць у системі державних заходів щодо охорони, відтворення та раціонального використання природних ресурсів країни. Захисні лісонасадження сприяють поліпшенню кліматичних і гідрологічних умов відкритої місцевості, раціональному освоєнню земельних і водних ресурсів, залученню до господарського використання малопродуктивних і непридатних земель, пісків, ярів і балок. Але для одержання бажаних результатів необхідно володіти повним обсягом інформації про життя лісу. Усе наведене дозволяє зробити висновок про необхідність ретельної охорони та вивчення лісів.

Природні ліси у степу формуються в долинах річок, на пристінах, у балках і ярах вододілів. Байрачні ліси приурочені переважно до еродованих правобережних схилів Дніпра та його припливів, а також до привододільно-балкових ландшафтів вододілів [4, с. 142]. Байрачні ліси являють собою наукову цінність для вивчення особливостей формування природних лісів, у яких знайшли притулок рідкісні та зникаючі види рослин і тварин. Крім цього, байрачні ліси можуть служити еталонами для створення протиерозійних насаджень, а також цінним фондом насіння деревних $\mathrm{i}$ чагарникових порід.

\section{Матеріал і методи досліджень}

Фітоценози 7 пробних площ байраку Капітанове (байрачні ліси північного варіанта) досліджено протягом 2004 року. Уздовж катени виконано 7 грунтових розрізів. Пробна ділянка ПД-1 розташована у верхній третині, ПД-2 - у середній і ПД-3 у нижній третині схилу північної експозиції, ПД-4 - у тальвегу балки, ПД-5 - у верхній третині, ПД-6 - у середній і ПД-7 - у нижній третині схилу південної експозиції.

\section{Результати та їх обговорення}

Байрак Капітанове розташований у двох кілометрах на захід від села Надіївка Новомосковського району Дніпропетровської області [3, с. 137]. На дні балки проті-

(C) К. М. Божко, 2007 2007. 15(1). 
кає струмок шириною близько 50 см. Усі пробні ділянки належать кварталу № 67 Новомосковського лісництва (рис.).

Пробна ділянка ПД-1 закладена у верхній третині пологого схилу в $5^{\circ}$ північної експозиції на відстані 110 м від орної ділянки на південь і 65 м на північ від тальвегу балки. Тип лісового біогеоценозу - клен гостролистий + ясен звичайний + дуб звичайний + липа серцелиста - клен польовий - бруслина бородавчаста + бузина чорна купина багатоквіткова + зірочник костянцевий + копитняк європейський. 3 Д 3 Я 3 Кг 1 Кп. Світлова структура - напівтіньова. Зімкнутість крон - 0,8. Мікрорельєф хвилястий із перепадами висот до $40 \mathrm{~cm}$. Умови зволоження - атмосфернотранзитні. Багато пориїв мишоподібних гризунів.

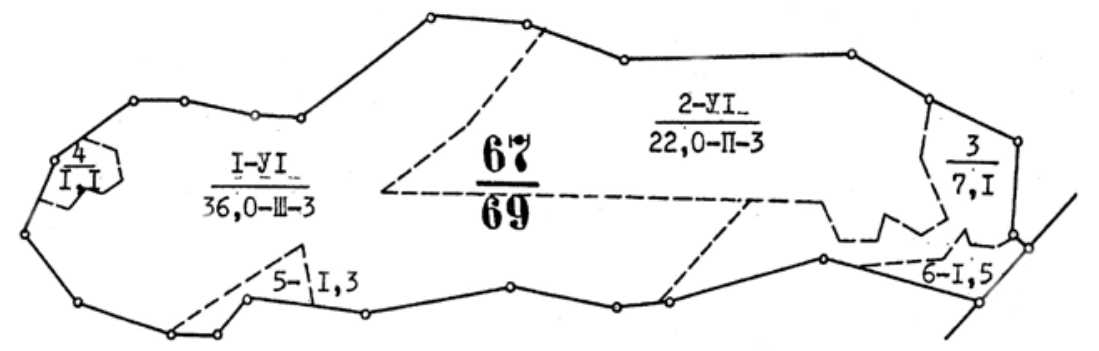

Рис. Схематичне зображення байраку Капітанове Новомосковського лісництва

У першому деревному під’ярусі представлені дуб звичайний (Quercus robur L.) сім'яний (діаметром 33 см, висотою 20 м, віком 40 років), ясен звичайний (Fraxinus excelsior L.) сім'яний (діаметром $44 \mathrm{~cm}$, висотою 22 м, віком 40 років) і порослевий (двостовбурний, діаметром 18-30 см), клен гостролистий (Acer platanoides L.) порослевий (діаметром $18 \mathrm{~cm}$, віком 15 років) і сім'яний (діаметром $28 \mathrm{cm,} \mathrm{висотою} 22 \mathrm{м}$, віком 40 років). У другому деревному ярусі домінують клен польовий (Acer campestre L.) сім'яний (діаметром $18 \mathrm{~cm}$, висотою 12 м, віком 15 років) і порослевий (діаметром $8 \mathrm{cm,} \mathrm{висотою} 10$ м, віком 10 років), поодиноко представлена липа серцелиста (Tilia cordata Mill.) порослева (діаметром $10 \mathrm{~cm}$, висотою 8 м, віком 10 років). Підріст - з ясена звичайного, клена гостролистого, клена польового, липи серцелистої; присутній самосів бруслини бородавчастої (Euonymus verrucosa Scop.). Загальне покриття травостою - 40 \% (табл. 1).

Таблиия 1

Біоекологічна паспортизація* травостою ПД-1,

Присамарський міжнародний біосферний стаціонар ім. О. Л. Бельгарда

\begin{tabular}{|c|l|c|c|c|c|c|c|}
\hline № & \multicolumn{1}{|c|}{ Найменування рослини } & Ярус & $\begin{array}{c}\text { Висота, } \\
\text { см }\end{array}$ & $\begin{array}{c}\text { Фаза } \\
\text { вегетації }\end{array}$ & $\begin{array}{c}\text { Рясність } \\
\text { за Друде }\end{array}$ & $\begin{array}{c}\text { Покриття, Життєвість, } \\
\%\end{array}$ & $\begin{array}{c}\text { бали } \\
\text { бра }\end{array}$ \\
\hline 1 & Stellaria holostea L. & $H_{2}$ & 12 & $\#,-, \sim$ & Cop $_{1}(\mathrm{gr})$ & 20 & 4 \\
\hline 2 & Polygonatum multiflorum (L.) & $H_{1}$ & 40 & $+, \sim,-$ & $\mathrm{Sp}$ & 1 & 4 \\
\hline 3 & Asarum europaeum L. & $H_{2}$ & 12 &,$- \sim$ & $\mathrm{Sol}$ & 1,5 & 4 \\
\hline 4 & Viola odorata L. & $H_{2}$ & 10 &,$- \sim$ & $\mathrm{Cop}_{1}(\mathrm{gr})$ & 10 & 4 \\
\hline 5 & Alliaria petiolata (Bieb.) & $H_{3}$ & $5-6$ & $\mathrm{v}$ & $\mathrm{Sol}$ & 1 & $3-4$ \\
\hline 6 & Urtica dioica L. & $H_{1}$ & 50 & - & Sol & $<1$ & 3 \\
\hline 7 & Anthriscus sylvestris (L.) & $H_{1}$ & 50 & $\mathrm{v}$ & Sol & $<1$ & 3 \\
\hline
\end{tabular}

Примітки: ярус: $H_{1}$ - найвищий ярус, $H_{2}$ - середній ярус, $H_{3}$ - найнижчий ярус; фаза вегетації: - - вегетує, - вегетує після плодоношення, v - стан розетки, + - нестиглі плоди, О - повне цвітіння, \# - зрілі плоди; рясність за Друде: un - одиничний екземпляр виду, sol - поодиноко (дуже мало), $\mathrm{sp}$ - рідко (мало), сор1 - дуже рідко, сор2 - розкидані (досить багато), сор3 - розсіяно (багато), soc - багато (суттєва перевага за числом особин), gr - групами. 
Пробна ділянка ПД-2 закладена у середній третині схилу (10 північної експозиції) у 120 м від ріллі на південь і 55 м 3 півночі від тальвегу балки. Тип лісового біогеоценозу - ясен звичайний - клен гостролистий + клен польовий + бруслина бородавчаста - купина багатоквіткова + конвалія звичайна + кінський часник + фіалка шершава + зірочник костянцевий. Світлова структура - напівтіньова. Зімкнутість крони - 0,8. Умови зволоження - атмосферно-транзитні. Режим зволоження СГ 2 . Опад із листя дуба звичайного та інших деревних порід (3 см). Вплив тварин і людей проявляється у збиранні лікарської сировини та декоративних рослин, присутні пориї мишоподібних гризунів.

У першому деревному ярусі представлений ясен звичайний порослевий (тристовбурний, діаметром 30-48 см, висотою 23 м, віком 40 років) і сім'яний (діаметром $30 \mathrm{~cm}$, висотою 22 м, віком 20 років). У другому деревному ярусі домінують клен польовий порослевий (діаметром 12 см, висотою 10 м, віком 10 років), клен гостролистий порослевий (діаметром $10 \mathrm{~cm}$, висотою 8 м, віком 10 років) і сім'яний (діаметром 10 см, висотою 9 м, віком 8 років), поодиноко представлена липа серцелиста (діаметром 9 см, висотою 10 м, віком 10 років). Підріст - із бруслини бородавчастої (Euonymus verrucosa Scop.) та європейської (E. europaea L.). У травостої домінує Stellaria holostea L. (табл. 2).

Таблиия 2

Біоекологічна паспортизація* травостою ПД-2,

Присамарський міжнародний біосферний стаціонар ім. О. Л. Бельгарда

\begin{tabular}{|c|c|c|c|c|c|c|c|}
\hline № & Найменування рослини & Ярус & $\begin{array}{c}\text { Висота, } \\
\text { см }\end{array}$ & $\begin{array}{c}\text { Фаза веге- } \\
\text { тації }\end{array}$ & $\begin{array}{l}\text { Рясність } \\
\text { за Друде }\end{array}$ & $\begin{array}{c}\text { Покриття, } \\
\%\end{array}$ & $\begin{array}{c}\text { Життєвість, } \\
\text { бали }\end{array}$ \\
\hline 1 & Stellaria holostea L. & $\mathrm{H}_{2}$ & 10 &,$- \sim$ & $\mathrm{Cop}_{1}$ (gr) & 15 & $3-4$ \\
\hline 2 & Polygonatum multiflorum (L.) & $H_{l}$ & 50 &,$- \sim$ & $\mathrm{Sp}$ & 5 & 4 \\
\hline 3 & Convallaria majalis L. & $\mathrm{H}_{2}$ & 15 &,$- \sim$ & $\mathrm{Sp}$ & 2 & 4 \\
\hline 4 & Alliaria petiolata (Bieb.) & $\mathrm{H}_{2}$ & 12 & $\mathrm{~V}$ & Sol & 5 & $3-4$ \\
\hline 5 & Viola odorata $\mathrm{L}$ & $\mathrm{H}_{2}$ & 10 &,-+ & $\mathrm{Cop}_{1}$ (gr) & $<1$ & 3 \\
\hline 6 & Asarum europaeum L. & $\mathrm{H}_{2}$ & 10 & - & Sol & $<1$ & 3 \\
\hline 7 & Scutellaria altissima L. & $H_{1}$ & 60 & $\sim$ & Sol & $<1$ & 4 \\
\hline 8 & Anthriscus sylvestris (L.) & $H_{l}$ & 40 & $\mathrm{~V}$ & Sol & 0,1 & 4 \\
\hline 9 & Urtica dioica $\mathrm{L}$. & $H_{1}$ & 30 & - & Sol & 0,1 & 3 \\
\hline
\end{tabular}

Примітка: див. табл. 1.

Пробна ділянка ПД-3 закладена у нижній третині схилу в $12^{\circ}$ північної експозиції. Тип лісового біогеоценозу - ясен звичайний + клен гостролистий + липа серцелиста - клен польовий - бруслина європейська + бузина чорна - купина багатоквіткова + копитняк європейський + фіалка шершава. Світлова структура - напівтіньова. Зімкнутість крони - 0,8. Умови зволоження - атмосферно-транзитні. Режим зволоження С $\Gamma_{2}$. Опад із листя дуба звичайного та інших деревних порід (3 см). Багато пориїв мишоподібних гризунів.

У першому деревному ярусі домінують ясен звичайний порослевий (діаметром 30 см, висотою 25 м, віком 35 років) і сім'яний (діаметром 50 см, висотою 25 м, віком 40 років), клен гостролистий сім'яний (діаметром 28 см, висотою 20 м, віком 20 років), липа серцелиста (діаметром 24 см, висотою 18 м, віком 15 років). У другому деревному ярусі представлені клен польовий сім'яний (діаметром $20 \mathrm{~cm}$, висотою 15 м, віком 15 років) та берест граболистий (діаметром $3 \mathrm{~cm}$, висотою 2,5 м, віком 4 роки). Чагарниковий підлісок сформований із береста граболистого, клена польового, бруслини європейської та бородавчастої (покриття 5 \%). Загальне покриття травостою $-50 \%$ (табл. 3). 
Біоекологічна паспортизація* травостою ПД-3, Присамарський міжнародний біосферний стаціонар ім. О. Л. Бельгарда

\begin{tabular}{|c|l|c|c|c|c|c|c|}
\hline № & \multicolumn{1}{|c|}{ Найменування рослини } & Ярус & $\begin{array}{c}\text { Висота, } \\
\text { см }\end{array}$ & $\begin{array}{c}\text { Фаза } \\
\text { вегетації }\end{array}$ & $\begin{array}{c}\text { Рясність } \\
\text { за Друде }\end{array}$ & $\begin{array}{c}\text { Покриття, } \\
\%\end{array}$ & $\begin{array}{c}\text { Життєвість, } \\
\text { бали }\end{array}$ \\
\hline 1 & Polygonatum multiflorum (L.) & $H_{1}$ & 40 &,$- \sim$ & $\mathrm{Sp}$ & 1 & 4 \\
\hline 2 & Viola odorata (L.) & $\mathrm{H}_{2}$ & 12 &,-+ & $\mathrm{Sp}$ & 2,5 & $3-4$ \\
\hline 3 & Asarum europaeum L. & $\mathrm{H}_{2}$ & 10 & - & $\mathrm{Sp}$ & 2 & 4 \\
\hline 4 & Alliaria petiolata (Bieb.) & $\mathrm{H}_{2}$ & 12 &,-+ & $\mathrm{Sp}$ & 5 & 4 \\
\hline 5 & Geranium robertianum L. & $H_{3}$ & 5 & $\mathrm{v}$ & $\mathrm{Sp}$ & $<1$ & 4 \\
\hline 6 & Glechoma hederacea L. & $H_{3}$ & 10 & $\mathrm{v}$ & $\mathrm{Sol}$ & 0,1 & $3-4$ \\
\hline 7 & Pulmonaria obscura Dumort & $\mathrm{H}_{2}$ & 15 & $\sim, \mathrm{v}$ & $\mathrm{Sol}$ & 1 & 4 \\
\hline
\end{tabular}

Примітка: див. табл. 1.

Пробна ділянка ПД-4 закладена у тальвегу балки на відстані 5 м від струмка. Тип лісового біогеоценозу - ясен звичайний + дуб звичайний - клен польовий - бузина чорна + глід оманливий - яглиця звичайна + кропива дводомна + медунка вузьколиста + копитняк європейський. Світлова структура - тіньова. Зімкнутість крони 0,9. Режим зволоження $\mathrm{C}_{3}$. Мікрорельєф хвилястий із перепадами висот до 30 см. Умови зволоження - атмосферне, грунтове. Багато пориїв мишоподібних гризунів.

У першому деревному ярусі домінують дуб звичайний сім'яний (діаметром 65 см, висотою 25 м, віком 60 років), ясен звичайний порослевий (чотиристовбурний діаметром 65 см, висотою 24 м, віком 60 років), клен польовий порослевий (діаметром $26 \mathrm{~cm}$, висотою 18 м, віком 40 років). У другому деревному ярусі - липа серцелиста (діаметром стовбура $12 \mathrm{~cm}$, висотою $12 \mathrm{м}$, віком 10 років). Підріст - 3 ясена звичайного, в'яза (діаметром 4 см, висотою 2,5 м, віком 8 років). Загальне покриття травостою - 80 \% (табл. 4).

Таблиия 4

Біоекологічна паспортизація* травостою ПД-4,

Присамарський міжнародний біосферний стаціонар ім. О. Л. Бельгарда

\begin{tabular}{|c|l|c|c|c|c|c|c|}
\hline № & \multicolumn{1}{|c|}{ Найменування рослини } & Ярус & $\begin{array}{c}\text { Висота, } \\
\text { см }\end{array}$ & $\begin{array}{c}\text { Фаза } \\
\text { вегетації }\end{array}$ & $\begin{array}{c}\text { Рясність } \\
\text { за Друде }\end{array}$ & $\begin{array}{c}\text { Покриття, } \\
\%\end{array}$ & $\begin{array}{c}\text { Життєвість, } \\
\text { бали }\end{array}$ \\
\hline 1 & Aegopodium podagraria L. & $H_{1}$ & 54 &,-+ & $\mathrm{Cop}_{3}(\mathrm{gr})$ & 50 & 5 \\
\hline 2 & Asarum europaeum L. & $\mathrm{H}_{2}$ & 10 &,$- \sim$ & $\mathrm{Cop}_{1}(\mathrm{gr})$ & 2 & 4 \\
\hline 3 & Urtica dioica L. & $H_{1}$ & 50 & - & Sol & $<1$ & 3 \\
\hline
\end{tabular}

Примітка: див. табл. 1.

Пробна ділянка ПД-5 закладена у нижній третині схилу в $15^{\circ}$ південної експозиції на відстані 5 м від тальвегу. Умови зволоження - атмосферно-транзитні. Тип лісового біогеоценозу - ясенево-пакленова діброва з бузиною чорною, копитняком європейським та зірочником костянцевим. Світлова структура - напівтіньова. Зімкнутість крони - 0,7. Режим зволоження $С \Gamma_{2}$. Мікрорельєф хвилястий. Мертвий покрив фрагментарний із листя деревних порід і відмерлих трав. Багато пориїв мишоподібних гризунів.

Ясен звичайний порослевий (тристовбурний діаметром 26-31 см, висотою 23 м, віком 60 років) і сім'яний (діаметром $52 \mathrm{cм}$, висотою 24 м, віком 40 років); дуб звичайний сім'яний (діаметром $44 \mathrm{~cm}$, висотою 25 м, віком 40 років) і порослевий (тристовбурний діаметром $30 \mathrm{~cm}$, віком 35 років), клен польовий сім'яний (діаметром $25 \mathrm{~cm}$, висотою 14 м, віком 20 років), липа серцелиста (діаметром 12 см, висотою 10 м, віком 10 років). 2 Д 5 Я 2 Кп 1 Л . Чагарниковий підлісок - з бузини чорної та 
бруслини європейської. У підрості домінують в'яз гірський, клени польовий та гостролистий. Загальне покриття травостою - 40 \% (табл. 5).

Пробна ділянка ПД-6 закладена у середній третині схилу в $20^{\circ}$ південної експозиції. Мікрорельєф хвилястий. Умови зволоження - атмосферно-транзитне притічновідтічне. Тип лісового біогеоценозу - ясенево-пакленова діброва. Світлова структура напівтіньова. Зімкнутість крони - 0,8. Режим зволоження СГ 2 . Мертвий покрив фрагментарний із листя деревних порід і відмерлих трав. $€$ пориї мишоподібних гризунів.

Біоекологічна паспортизація* травостою ПД-5,

Таблиия 5

Присамарський міжнародний біосферний стаціонар ім. О. Л. Бельгарда

\begin{tabular}{|c|l|c|c|c|c|c|c|}
\hline № & \multicolumn{1}{|c|}{ Найменування рослини } & Ярус & $\begin{array}{c}\text { Висота, } \\
\text { см }\end{array}$ & $\begin{array}{c}\text { Фаза } \\
\text { вегетації }\end{array}$ & $\begin{array}{c}\text { Рясність } \\
\text { за Друде }\end{array}$ & $\begin{array}{c}\text { Покриття, } \\
\%\end{array}$ & $\begin{array}{c}\text { Життєвість, } \\
\text { бали }\end{array}$ \\
\hline 1 & Asarum europaeum L. & $H_{3}$ & 8 &,$- \sim$ & $\mathrm{Cop}_{1}(\mathrm{gr})$ & 2 & 4 \\
\hline 2 & Polygonatum multiflorum (L.) & $H_{2}$ & 20 &,$- \sim$ & $\mathrm{Sp}$ & 1 & $3-4$ \\
\hline 3 & Stellaria holostea L. & $H_{2}$ & 20 & - & $\mathrm{Sp}$ & 2 & 4 \\
\hline 4 & Anthriscus sylvestris (L.) & $H_{1}$ & 35 & $\mathrm{v}$ & $\mathrm{Sol}$ & $<1$ & 4 \\
\hline 5 & Viola odorata L. & $H_{3}$ & 8 &,-+ & $\mathrm{Cop}_{1}(\mathrm{gr})$ & 4 & $3-4$ \\
\hline 6 & Urtica dioica L. & $H_{1}$ & 50 & - & $\mathrm{Cop}_{1}(\mathrm{gr})$ & $<1$ & $3-4$ \\
\hline 7 & Aegopodium podagraria L. & $H_{1}$ & 30 & $\mathrm{v}$ & $\mathrm{Cop}_{1}(\mathrm{gr})$ & 2 & 4 \\
\hline 8 & Geum urbanum L. & $H_{1}$ & 50 & $\mathrm{O},+$ & $\mathrm{Un}$ & $<1$ & 4 \\
\hline 9 & Chaerophyllum temulum L. & $H_{3}$ & 4 & $\mathrm{v}$ & $\mathrm{Sp}$ & $<1$ & 4 \\
\hline
\end{tabular}

Примітка: див. табл. 1.

У першому деревному ярусі - ясен звичайний порослевий (діаметром $45 \mathrm{~cm}$, висотою 24 м, віком 50 років), дуб звичайний сім'яний (діаметром 28 см, висотою 19 м, віком 25 років) і порослевий (діаметром 44 см, висотою 20 м, віком 35 років). У другому деревному ярусі - клен польовий сім'яний (діаметром 10 см, висотою 8 м, віком 10 років). 3 Д 4 Я 3 Кп. Підріст із клена польового, в’яза. Загальне покриття травостою $50 \%$ (табл. 6).

Табличя 6

Біоекологічна паспортизація* травостою ПД-6,

Присамарський міжнародний біосферний стаціонар ім. О. Л. Бельгарда

\begin{tabular}{|c|c|c|c|c|c|c|c|}
\hline № & Найменування рослини & Ярус & $\begin{array}{c}\text { Висота, } \\
\text { см }\end{array}$ & $\begin{array}{c}\text { Фаза } \\
\text { вегетації }\end{array}$ & $\begin{array}{l}\text { Рясність } \\
\text { за Друде }\end{array}$ & $\begin{array}{c}\text { Покриття, } \\
\text { \% } \\
\end{array}$ & $\begin{array}{c}\text { Життєвість, } \\
\text { бали } \\
\end{array}$ \\
\hline 1 & Pulmonaria obscura Dumort & $\mathrm{H}_{2}$ & 16 & $\mathrm{~V}, \sim$ & $\mathrm{Cop}_{1}$ (gr) & 2 & $4-5$ \\
\hline 2 & Scutellaria altissima L. & $H_{1}$ & 45 & $\#, \sim$ & $\mathrm{Sp}$ & 2 & 4 \\
\hline 3 & Stellaria holostea L. & $\mathrm{H}_{2}$ & 12 & - & $\mathrm{Cop}_{1}$ (gr) & 3 & 4 \\
\hline 4 & Viola odorata L. & $\mathrm{H}_{3}$ & 5 &,-+ & $\mathrm{Sp}$ & 2 & $3-4$ \\
\hline 5 & Chaerophyllum temulum $\mathrm{L}$. & $\mathrm{H}_{3}$ & 5 & $\mathrm{v}$ & $\mathrm{Sp}$ & 1 & 4 \\
\hline
\end{tabular}

Примітка: див. табл. 1.

Пробна ділянка ПД-7 закладена у верхній третині схилу в $20^{\circ}$ південної експозиції. Тип лісового біогеоценозу - ясенево-пакленова діброва 3 фіалкою шершавою. Мікрорельєф хвилястий із перепадами висот до 40 см. Умови зволоження - атмосферно-транзитні. Зімкнутість крони $-0,6$. Режим зволоження С $\Gamma_{1-2}$ (табл. 7).

Ясен звичайний порослевий (двостовбурний діаметром 24-30 см, висотою 23 м, віком 30 років) і сім'яний (діаметром 26 см, висотою 18 м, віком 20 років), дуб звичайний сім'яний (діаметром $27 \mathrm{~cm}$, висотою 15 м, віком 30 років) і порослевий (діаметром $33 \mathrm{~cm}$, висотою 18 м, віком 35 років), клен польовий (діаметром 6 см, висотою 10 м, віком 10 років). 5 Д 3 Я 2 Кп. 2007. 15(1). 
Біоекологічна паспортизація* травостою ПД-7, Присамарський міжнародний біосферний стаціонар ім. О. Л. Бельгарда

\begin{tabular}{|c|l|c|c|c|c|c|c|}
\hline № & \multicolumn{1}{|c|}{ Найменування рослини } & Ярус & $\begin{array}{c}\text { Висота, } \\
\text { см }\end{array}$ & $\begin{array}{c}\text { Фаза веге- } \\
\text { тації }\end{array}$ & $\begin{array}{c}\text { Рясність по } \\
\text { Друде }\end{array}$ & $\begin{array}{c}\text { Покриття, } \\
\%\end{array}$ & $\begin{array}{c}\text { Життєвість, } \\
\text { бали }\end{array}$ \\
\hline 1 & Viola odorata L & $H_{3}$ & 10 &,-+ & Cop 1 (gr) & 25 & 4 \\
\hline 2 & Polygonatum multiflorum (L.) & $H_{1}$ & 35 & $\sim,-$ & $\mathrm{Sol}$ & $<1$ & 4 \\
\hline 3 & Geum urbanum L. & $H_{2}$ & 25 & $\mathrm{v}$ & $\mathrm{Sol}$ & 1 & 4 \\
\hline 4 & Chaerophullum temulum L. & $H_{3}$ & 4 & $\mathrm{v}$ & $\mathrm{Sp}$ & 1 & 4 \\
\hline 5 & Stellaria holostea L. & $H_{3}$ & 10 & - & $\mathrm{Sp}, \mathrm{Cop} \mathrm{p}_{1}(\mathrm{gr})$ & 1 & $3-4$ \\
\hline 6 & Pulmonaria obscura Dumort & $\mathrm{H}_{2}$ & 15 & $\mathrm{v},-$ & $\mathrm{Sp}$ & 1 & 4 \\
\hline
\end{tabular}

Примітка: див. табл. 1.

Чагарниковий підлісок із бузини чорної, бруслини бородавчастої та європейської. Загальне покриття травостою $-45 \%$.

\section{Висновок}

Результати визначення біоекологічних характеристик фітоценозу семи пробних ділянок північного варіанта байрачних лісів південно-східної України (на прикладі байраку Капітанове) свідчать про те, що видовий склад фітоценозу небагатий (36 видів у деревостані та 4-8 видів у травостої). Це пов'язано 3 напівтіньовою світловою структурою та високою зімкнутістю крон $(0,4-0,9)$. Найбільший видовий склад фітоценозу властивий для пробних ділянок з освітленою світловою структурою та меншою зімкнутістю крон.

\section{Бібліографічні посилання}

1. Адерихин П. Г. Влияние лесной растительности на черноземы // Русский чернозем (100 лет после Докучаева) / П. Г. Адерихин, А. Л. Бельгард, С. В. Зонн и др. - М.: Наука, 1983. - С. 117-126.

2. Байрачные леса бывшей порожистой части Днепра - составная часть экологической сети юга Украины / А. П. Травлеев, Н. А. Белова, А. В. Боговин, А. А. Дубина // Екологія та ноосферологія. - 2005. - № 3-4. - С. 75-94.

3. Белова Н. А. Экология, микроморфология, антропогенез лесных почв степной зоны Украины. - Д.: ДГУ, 1997. - 264 с.

4. Белова Н. А. Естественные леса и степные почвы / Н. А. Белова, А. П. Травлеев. - Д.: ДГУ, 1999. - С. 142-143.

5. Бельгард А. Л. Байрачные леса бывшей порожистой части Днепра // Научн. зап. ДГУ. 1940. - С. 99-104.

6. Бельгард А. Л. Лесная растительность юго-востока УССР. - К.: КГУ, 1950. - С. 260-265.

7. Зонн С. В. Географо-генетические аспекты почвообразования, эволюции и охраны почв / С. В. Зонн, А. П. Травлеев. - К.: Наукова думка, 1989. - 216 с.

8. Ревут И. Б. Физика почв. - Л.: Колос, 1964. - С. 319.

9. Тарасов В. В. Флора Дніпропетровської та Запорізької областей. Судинні рослини. Біолого-екологічна характеристика видів. - Д.: ДНУ, 2005. - 276 с.

10. Травлеев А. П. Генетические аспекты взаимодействия лесной растительности с почвами в условиях степи // Вопросы степного лесоведения и охраны природы. - Д.: ДГУ, 1977. C. $40-45$.

11. Яковенко В. Н. Особенности зоогенного структурообразования лесных черноземов байрачных лесов Присамарья // Екологія та ноосферологія. - 1999. - № 4. - С. 77-82.

Надійшла до редколегії 06.11.2006 